\title{
Engineering and Motherhood: An Unspoken Combination
}

\author{
Michele M. Putko \\ United States Military Academy
}

\begin{abstract}
The representation of females in the engineering world has grown considerably in recent decades. The message heard nation wide is that femles are fully capable of studying, practicing, and teaching engineering. Yet an issue that is rarely addressed in a public forum is that of combining a career in engineering with motherhood. It is a subject female engineers hesitate to discuss in their quest to be accepted in the male-dominated profession of engineering. The distinct roles of a mother and an engineer are viewed by many to be incongruous. As a mother, and an engineering educator, I wish to share my experiences and thoughts related to my dual role. This paper will discuss personal experiences and issues related to choosing both engineering and motherhood.
\end{abstract}

\section{"Equality" ?}

Although many opinions and stereotypes still exist in our society, I dare to say that I, as an engineering educator, have equal status and salary compared to any male who has worked in my position. I pay homage to the trailblazers, who bonded together decades ago and developed a powerful women's movement that made it possible for me to claim "equality." As a woman with a career, I am free from the "oppression" of a life dedicated to, and solely revolving around, a husband and children. Yet, I cannot help but notice that I am not "equal" to my co-workers; I am a mother. Although I am free of the prewomen's movement "oppression" associated with motherhood, I am not free of strong maternal instincts and a great dedication to my husband and children.

For many people, the combination of titles, "mom and engineer" is too unsettling to discuss in a public setting. In order to understand the perceptions associated with my position as a mother and female engineering educator, I find it interesting to note the very recent history of females in engineering related careers.

\section{Women in Engineering: A History}

The male exclusivity of engineering first began to wear off with the invention of the steam engine and the discovery of electricity'. As the world began to rely more on machinery and less on brawn, all that was required to be an engineer was an aptitude for mathematics, a scientific curiosity, and a desire to create useful things. Yet most females did not know what an engineer did. In the minds of most women, engineering was a "masculine" profession.

World War II served as an impetus to get females involved in engineering. The war provided females with the opportunity to work in many non-traditional jobs. "Rosie the Riviter" is still a national symbol of the female contribution to the war effort. During the war, females were not only making a great contribution on the assembly lines but were also working as engineers. Women were praised by the government for their work supporting the war effort on the home front. However, once World War II ended everything changed. With the conclusion of the war, "women 
engineers who had been courted, trained, and praised by both industry and government, were suddenly urged to go 'back to the kitchen.' Women engineers who had been welcomed with open arms during the war years were now told to forget a career in engineering" ${ }^{2}$. Society was not ready to accept women engineers.

Many of the women engineers of the 1940's resisted the push back into the home. Those that continued working as engineers is the late 1940's and 1950's were considered "curiosities" by their male counterparts, for society no longer considered engineering a suitable career for women. Many of the women engineers bonded and gave support to each other during these frustrating years. The result of this bonding led to the official formation of the Society of Women Engineers, (SWE) in 1950, an organization which remains strong today ${ }^{3}$.

A small number of female engineers quietly persevered through the 1950's and 1960's. In the women's movement of the early 1970's, feminists made a huge push to escape from the "oppression" then associated with being female. Women asked for the same opportunities as men. Popular slogans of the time were, "Equal Opportunity," and "Equal Pay for Equal Work." Women wanted to be able to enter the world of a traditional male value system, one in which meaningful achievement was related to work, status, and salary'. During the 1970's the US government passed much legislation signifying a new era in history. The legislation opened many doors for women. The new opportunities to work, divorce, and control reproduction signaled an end to "oppression" and an opportunity to pursue non-traditional careers, such as engineering.

\section{Women and Engineering in the 1990's}

Following the feminist movement of the 1970's, there was a significant increase in the numbers of females pursuing engineering. Two decades since the movement, the combination of terms, "Women and Engineering" is in vogue. It is currently politically correct to have women on your faculty, to have high numbers of females enrolled in engineering programs, and to support programs that attract females to science.

The following statements are intended to encourage a women interested in engineering:

. Women are as capable as men.

. Females are being accepted and integrated into the engineering world.

- A female engineer is no different than a male engineer.

The above statements imply equality and are perhaps politically correct, yet the subliminal message in these statements is that women are being welcomed into engineering as though they were men. A woman can be an engineer, just as a man can.

Many female engineers have shed and are shedding the old-fashioned stereotypical views of a nurturing housewife and mother and adopting "new stereotypical views" as ambitious, competitive, and aggressive leaders. Although I believe the new stereotypical views describe a female engineer of the 1990's, I also believe the "old-fashioned" wife and mother has not left the picture. I believe that a contented, old-fashioned wife and mother may still be alive behind the successful woman engineer.

\section{"I Had You Pegged as Childless"}

Recently I became a visibly pregnant engineering educator. Most of my colleagues greeted me with the sociably accepted remark of, "Congratulations !" One of my colleagues said to me, "Congratulations, I heard you' re going to be a mom." I answered, "Yes, for the sixth time." With a very astonished expression on his face, this colleague said to me,"1 had you pegged as childless." As 1 walked away from our conversation, I became curious as to why I was "pegged as childless", I asked my colleague why he thought I had no children. He stated that he assumed I had no children simply because I was a successful military officer and engineering educator. To my colleague the roles of engineering educator and motherhood seemed incongruous. 
Everyone knows that there are some engîneers who are also morns but who are they? You cannot tell by looking at them or speaking to them__s motherhood something a women can simply not talk about in her quest to be accepted in the still -male-dominated field of engineering? Is motherhood and engineering considered a "curiosity" just as the female engineers were the “curiosities" of the 1940's and 1950's?

Perhaps for people who are trying to say the right thing in this very sensitive world, the term mother is a "sexist label" and thus should be avoided in conversation. I do not take offense at being labeled either nurturing or aggressive. I am thankful for having the opportunity to work as an engineering educator, and I am also thankful to have the-opportunity to fulfill my maternal instincts through raising children. I am humored by the seeming reluctance of many to admit that a women can successfully be both an engineer and a mother.

\section{Engineers/Mothers, Are You Out There?}

Are women engineers sacrificing motherhood to be accepted in the "man's world"? I do not know what percentage of female engineers are also mothers, yet I do know at the United States Military Academy there are very few, if any, fellow engineering educators who are mothers. I am well aware that the norms at West Point may be much more "traditional" than civilian society.

Nearly every study shows that there is a strong desire among the most diverse groups of women to become mothers ${ }^{5}$. Would such results hold true for a population of female engineers? All species of females have a maternal instinct which keeps the species alive. When females become engineers, is there an intentional suppression of the maternal instinct in order to be accepted in the male-dominated profession?

\section{Through a Mother's Eyes}

I laugh when my youngest daughter tells me she wants to grow up to be a teacher at West Point "like mom." This is amusing to me, for I know that while she has a non-traditional mother, the chances of her being highly educated and entering a non-traditional career path are much greater than other girls her age'. I smile when I have the opportunity to tell female cadets how wonderful and fulfilling life is as mother, and I nod as they often share with me secrets revealing their "womanly instincts."

My hope is to dispel the notion that a career in engineering is incompatible with motherhood. Perhaps a decade from now, society will accept the "old-fashioned mom" as the "modern engineer."

\section{References}

1. Kindya, Marta, Four Decades of the Society of Women Engineers, The Society of Women Engineers, 1990.

2. Ibid, p. 10.

3. Ibid.

4. Peck, Ellen, A Funny Thing Happened on the Way to Equality, Prentice Hall, Inc. Englewood Cliffs, New Jersey, 1975.

5. Bernard, Jessie, The Future of Motherhood, Dial Press, New York, 1974.

6. Ibid.

\section{MICHELE M. PUTKO}

Michele M. Putko graduated from the United States Military Academy at West Point in 1983. Commissioned in the US Army Ordnance Corps she has served both in the United States and abroad. After receiving her MS in Mechanical Engineering from Auburn University in 1992, she joined the Department of Civil and Mechanical Engineering, United States Military Academy where she is currently the Course Director for EM 301, Thermodynamics. 